Daniel J. Galvin*

\title{
Party Domination and Base Mobilization: Donald Trump and Republican Party Building in a Polarized Era
}

https://doi.org/10.1515/for-2020-2003

\begin{abstract}
Since the 2016 election, President Trump has achieved unparalleled dominance over the Republican Party. He has also given his party a central role in his reelection campaign and invested heavily in its organizational capacities. This dual approach to party leadership - domination paired with organizational investment - bears a strong resemblance to the way every Republican president since Eisenhower interacted with his party, different only in degree. Where Trump's party leadership diverges qualitatively from past patterns is in its apparent purposes. Previous Republican presidents dominated and invested in their party for the explicit purpose of building a new majority in American politics. Reaching out to new demographic groups and trying to persuade them to join the party was integral to this project. Trump, in contrast, has (thus far) predominantly pursued a base-mobilization strategy. Rather than fan out horizontally in search of new groups to join the party coalition, Trump's strategy drills down vertically to penetrate and deepen his base. Instead of trying to diversify the GOP and extend its reach, his strategy aims to swell the number of like-minded supporters who are active in electoral and party politics (while suppressing, demobilizing, and delegitimizing the opposition party). By setting into motion a mutually reinforcing cycle of party domination and base mobilization, and amplifying its effects through organizational investment, Trump has turned his party into a formidable vehicle for advancing his personal purposes and augmenting his power - while raising troubling questions about the stability of American democracy. This article examines Trump's party leadership to date, compares it to previous presidential party leadership projects, and considers the implications.
\end{abstract}

Keywords: presidential party leadership, partisan polarization, party domination, party-building

Recent reports have drawn attention to two defining characteristics of President Trump's first-term party leadership. First and most conspicuously, he has achieved

*Corresponding author: Daniel J. Galvin, Department of Political Science, Institute for Policy Research, Northwestern University, Evanston, IL, USA, E-mail: galvin@northwestern.edu 
unparalleled dominance over the Republican Party. He has thoroughly personalized its organization, deployed it instrumentally to promote his personal brand of politics, and used carrots and sticks to root out opponents, stifle dissent, and demand fealty to his administration from elected Republicans at all levels of government. ${ }^{1}$ Second, he has amalgamated his 2020 reelection campaign with the party apparatus, creating a "single, streamlined entity," and invested heavily in its organizational capacities. ${ }^{2}$ For example, before COVID-19 stay-at-home orders took effect, Trump's large "personality cult” campaign rallies were also carefully orchestrated party-building events designed for "massive data capturing," new donor recruitment, volunteer outreach, activist training, message testing, and base-building. ${ }^{3}$ Rather than push his party to the sidelines, as President Obama did to the Democratic Party, Trump has given the Republican Party a central role in his reelection campaign and enabled it to reap the benefits of the experience. ${ }^{4}$

Although Trump's behavior often seems utterly lacking in precedent, this dual approach to party leadership - domination paired with organizational investment actually looks quite familiar. It bears a strong resemblance to the way every Republican president since Eisenhower interacted with his party, as detailed in my book Presidential Party Building (2010). ${ }^{5}$ Along these two dimensions, Trump's approach appears to represent the most extreme manifestation of the Republican pattern to date.

But where Trump's party leadership diverges qualitatively from his Republican predecessors' is in its apparent purposes. Previous Republican presidents took control of their party and invested in its organizational capacities for the explicit purpose of building a new majority in American politics. Reaching out to new demographic groups - including a range of racial, ethnic, religious,

1 Jonathan Martin and Maggie Haberman, "Fear and Loyalty: How Donald Trump Took Over the Republican Party,” The New York Times, December 21, 2019; Perry Bacon Jr., “Trump completed his takeover of the GOP in 2019," FiveThirtyEight, December 23, 2019; Rachel Bade, “Trump's takeover of GOP forces many House Republicans to head for the exits,” The Washington Post, September 22, 2019.

2 Alex Isenstadt, "Trump launches unprecedented reelection machine," Politico, December 18, 2019; Alex Isenstadt, "Trump campaign moves to stave off mayhem at 2020 convention,” Politico, January 7, 2019; Danny Hakim and Glenn Thrush, "How the Trump Campaign Took Over the G.O.P.” The New York Time, March 9, 2020.

3 Jonathan Swan and Margaret Talev, "How Trump wins in 2020," Axios, December 14, 2019; David M. Drucker, “GOP fears Trump 'election diet of red meat' will overshadow economy in 2020," Washington Examiner, January 9, 2020.

4 Daniel J. Galvin, “Obama built a policy legacy. But he didn’t do enough to build the Democratic Party,” The Washington Post - Monkey Cage, November 16, 2016.

5 Daniel J. Galvin, Presidential Party Building: Dwight D. Eisenhower to George W. Bush (Princeton: Princeton University Press, 2010). 
geographic, income, occupation, and age groups - and trying to persuade them to join the party was integral to this project. Gerald Ford called it the "politics of addition." Establishing formal outreach programs within the Republican Party apparatus and institutionalizing party-group relations within the executive branch, they sought to maximize votes in the near term while cementing the allegiance of new groups to the GOP for the long term. ${ }^{7}$ For these Republican presidents, majority-building and party-building were one and the same.

Trump, in contrast, has (thus far) predominantly pursued a base-mobilization strategy. By this I mean his top priorities are to agitate, energize, and mobilize his most enthusiastic supporters to volunteer for the joint Trump-RNC campaign and vote Republican; enlist them to recruit their friends, families, and neighbors to do the same; and identify first-time and low-propensity voters who already strongly support the president and register them to vote. This approach has undoubtedly brought new voters into the Republican Party. But it is different from the outreachfocused, coalition-building strategy pursued by his Republican predecessors. Rather than fan out horizontally in search of new groups to join the party coalition, Trump's strategy drills down vertically to penetrate and deepen his base. ${ }^{8}$ Instead of trying to diversify the GOP and establish durable connections with a wider range of voters, Trump's strategy aims to swell the number of like-minded supporters who are active in electoral and party politics. When asked by Time magazine if he needed to reach out to swing voters ahead of the 2020 election, the President responded: "I think my base is so strong, I'm not sure that I have to do that."9

To be sure, electoral and party-building strategies always combine some elements of both base-mobilization and outreach, turnout-boosting and coalitionbuilding, rallying the party faithful and appealing to swing voters. How any president balances these strategic imperatives will always be a matter of degree and emphasis. For example, even as the Trump-RNC 2020 campaign prioritizes base mobilization, it also seeks to win back the "DJT disengagers" who voted for Trump in 2016 but "were repelled by his behavior and voted against Republicans in

6 Ibid., 115.

7 On the institutionalization of party-group relations in the executive branch since Nixon, see Katherine Krimmel, “The Efficiencies and Pathologies of Special Interest Partisanship," Studies in American Political Development 31 (2017): 149-69.

8 Jonathan Allen, "Inside Trump's all-about-that-base 2020 strategy,” NBC News, April 8, 2019.

9 “Donald Trump's Interview With TIME on 2020,” TIME, June 20, 2019. Trump campaign manager Brad Parscale's mantra is "turnout, turnout, turnout ... People all think you have to change people's minds. You have to get people to show up that believe in you.” See Brian Bennett, "'My Whole Life Is a Bet.' Inside President Trump's Gamble on an Untested Re-Election Strategy,” TIME, June 20, 2019. 
the 2018 midterms" - especially white suburban women - and it has recently made a series of overt appeals to African-American voters as well. ${ }^{10}$ As the election approaches, the campaign will undoubtedly feel pressure to shift more resources to swing-voter outreach in key battleground states where likely Democratic nominee Joe Biden jumped to an early lead (in April 2020). ${ }^{11}$ In the same way, even as earlier Republican presidents prioritized outreach, coalition expansion, and persuasion, they also worked hard to energize and mobilize the Republican base at election time. As partisan polarization has grown, the balance has appeared to shift toward more base-centered approaches. George W. Bush famously focused more on base mobilization than his predecessors, devoting equal resources to "base motivation" and "swing," as Bush's 2004 chief strategist Matthew Dowd put it. $^{12}$ Trump's strategy, in turn, has been called the "George W. Bush strategy on steroids." 13 What stands out, in other words, is the relative extremity of Trump's approach as compared to his predecessors' - and how it has complemented and reinforced his efforts to dominate his party.

By replicating the main party-building tactics of his Republican predecessors (domination and organizational investment) but swapping their majority-building purposes for his base mobilization-centered strategy, Trump has managed to bring about a stunning - and analytically illuminating - degree of congruence to the president-party relationship, resolving many of the tensions that bedeviled earlier Republicans. What's more, by setting into motion a mutually reinforcing cycle of party domination and base mobilization, and amplifying its effects through organizational investment, Trump has turned his party into a formidable vehicle for advancing his personal purposes and augmenting his political power. As I will discuss, Trump's tactics and strategies have been complementary in ways that have generated the semblance of collective approbation for his more questionable

10 Maggie Haberman, Annie Karni and Jonathan Martin, “On Trump’s To-Do List: Take Back The Suburbs. Court Black Voters. Expand the Electoral Map. Win.” The New York Times, February 8, 2020; https://twitter.com/i/status/1224119370839994369; and Jonathan Swan and Margaret Talev, "How Trump wins in 2020," Axios, December 14, 2019; Greg Sargent, "The Trump Campaign is Worried about Suburban Women. For Good Reason.” The Washington Post, August 21, 2019; Jonathan Allen, "Inside Trump's all-about-that-base 2020 strategy," NBC News, April 8, 2019; Michael A. Cohen, "Trump rallies his base, but he's not growing it," The Boston Globe, June 21, 2019; A. B. Stoddard, "Dems Beware - the RNC is Crushing it," Real Clear Politics, October 25, 2019. 11 Robert Draper, “Can the Trump Campaign Rewrite the Story of the Trump Presidency?” The New York Times Magazine, April 28, 2020; Alex Isenstadt, “Trump’s poor poll numbers trigger GOP alarms over November," Politico, April 24, 2020.

12 "Karl Rove, the Architect: 2004: The Base Strategy,” Frontline (PBS), https://www.pbs.org/ wgbh/pages/frontline/shows/architect/rove/2004.html.

13 Alex Isenstadt, “Trump Drives Massive Turnout in Primaries Despite Token Opposition,” Politico, February 16, 2020. 
behaviors and controversial judgment calls; reduced the likelihood that intraparty forces will provide an effective check on his abuses of power; reinforced extreme partisan polarization; and bolstered his efforts to suppress, demobilize, and delegitimize the opposition party.

It is too soon to say whether these dangers are real or exaggerated - or whether Trump's presidency marks the beginning of a new pattern of presidential party domination or is but an aberration. As discussed below, Obama's recent neglect of the Democratic Party, remarkably consistent with the behavior of his Democratic predecessors, suggests that the authoritarian style of party leadership may remain a distinctly Republican phenomenon. But events continue to unfold at a dizzying pace, and prediction is a hazardous business, especially in the Trump era. All the more reason to pause and take stock of the political dynamics we are watching unfold. How should we characterize Trump's party leadership to date, and what does it signify? These questions are best addressed by putting Trump's relationship with his party in comparative-historical perspective. ${ }^{14}$

\section{The Logic of President-Party Relations}

By mimicking the main tactics of his Republican predecessors (party domination paired with organizational investment) but jettisoning their outward-reaching, "Downsian" party-building purposes, Trump directs our attention to the crucial but understudied relationship between tactics and strategies in presidential party leadership projects.

Generally speaking, presidents have wide latitude to choose how they will interact with their parties and which strategic goals they will direct their parties to pursue. ${ }^{15}$ Some tactics and strategies, however, are likely to be more congruent, complementary, and mutually reinforcing than others. For example, in their efforts to pair party domination and organizational investment with an outreachcentered, majority-building strategy, Republican presidents prior to Trump often struggled to bring their tactics and strategies into congruence, finding that each

14 Also see Robert C. Lieberman, Suzanne Mettler, Thomas B. Pepinsky, Kenneth M. Roberts and Richard Valelly, "The Trump Presidency and American Democracy: A Historical and Comparative Analysis,” Perspectives on Politics 17, 2 (2019): 470-479; Nicholas F. Jacobs, Desmond King and Sidney M. Milkis, "Building a Conservative State: Partisan Polarization and the Redeployment of Administrative Power," Perspectives on Politics 17, 2 (2019): 453-469.

15 Of course, different contextual conditions will tend to generate different strategic imperatives. See, for example, Daniel J. Galvin, "Presidential Partisanship Reconsidered: Eisenhower, Nixon, Ford, and the Rise of Polarized Politics.” Political Research Quarterly no. 66, 1 (2013):46-60. For further discussion of the structural and personal factors motivating Trump's behavior, see below. 
tended to undermine the other. By employing these same tactics in pursuit of a predominantly base-centered strategy, Trump has shown us what can happen when the president's methods and purposes are better aligned. Before getting into the historical details, let us briefly consider the underlying logic.

If the president's paramount partisan objective is to deepen and mobilize his/ her base, there is no need for a diversity of viewpoints within the party. A unified, homogenous party that toes the White House line will do just fine. In fact, a party in conformity with the president's personal brand of politics will be more efficient and effective at pursuing the base-mobilization strategy - which provides an incentive for the president to assert his/her dominance over the party, personalize its message, and carefully shape the composition of its leadership. Domination of the party, in other words, complements the base-mobilization strategy. Party domination and base-mobilization are also mutually reinforcing over time: Once dissenters and nonconformists have been expelled or silenced, the party leaders that remain are those most committed to the president and his/her basemobilization strategy; further base mobilization then brings into the party more loyalists and true believers, who promote further base mobilization; and so on. Buttressing all of this with investments in organizational systems and processes geared toward deeper base penetration and more vigorous base mobilization, and a kind of lock-in effect occurs, propelling the whole project forward.

Compare this to the more outreach-focused, coalition-building strategy. The purpose of this strategy is to incorporate into the party new constituencies who do not currently identify with the party. These voters may find certain parts of the president's or the party's agenda appealing, but their support cannot be taken for granted: these are the swing voters, the ticket splitters, the "marginal" voters they are the opposite of the president's or the party's base. ${ }^{16}$ Reaching out to these voters may be necessary to advance the president's strategic majority-building goals, but it is inherently incompatible with his/her interest in personalization and control of the party. Rather than generate responsiveness and reliability, it invites instability and unpredictability: Once the president sets outreach programs in

16 According to William Mayer: "In simple terms, a swing voter is, as the name implies, a voter who could go either way, a voter who is not so solidly committed to one candidate or the other as to make all efforts at persuasion futile. If some voters are firm, clear, dependable supporters of one candidate or the other, swing voters are the opposite: those whose final allegiance is in some doubt all the way up until election day. Put another way, swing voters are ambivalent or, to use a term with a somewhat better political science lineage, cross-pressured." William G. Mayer, "What Exactly is a Swing Voter? Definition and Measurement," in The Swing Voter in American Politics, ed. William G. Mayer, (Brookings Institution Press, 2008): 1-31. On “marginal” voters, see Anthony Fowler, "Regular Voters, Marginal Voters and the Electoral Effects of Turnout," Political Science Research and Methods 3 (2015): 205-219. 
motion, it is difficult to know where they will lead. New constituencies, once aroused, will attract new candidates; new candidates, in turn, will attract a wider range of new constituencies, and so on. Add to this organizational investments in new party structures and processes - such as new party offices in new locations or new group outreach programs - and the resulting efficiency gains and feedback loops can lend a stickiness to the whole endeavor. ${ }^{17}$ Pretty soon, the outreach project has taken on a life of its own; the president has lost control; and newly empowered forces have begun to move the party in new, unexpected directions.

This latter scenario describes well the experiences of Trump's Republican predecessors. Serving during less polarized times, these presidents pursued predominantly outreach-centered strategies. Although each made headway in expanding his party's appeal to new groups, most struggled to bring their partybuilding tactics and strategies into congruence. Sometimes new groups were less supportive of the president than expected; sometimes the president's efforts to personalize the party undercut his efforts to expand it; and sometimes old groups rejected overtures to new groups, producing division and rancor and leaving the president caught in the crossfire. Seldom was the outreach-centered strategy executed seamlessly and rarely did it redound to the president's personal political advantage. ${ }^{18}$ Most often, presidents lost control of the party-building project and found themselves more politically vulnerable than they were before.

By bringing his party-building tactics and strategies into greater alignment than his predecessors, Trump has thus far managed to steer clear of many of those pitfalls while generating a surprising degree of apparent unity in the GOP. To draw out the significance of Trump's novel combination of tactics and strategies, let us flesh out the historical contrast in a bit more detail.

\section{The Republican Party-Building Pattern}

Like Trump, every Republican president from Dwight D. Eisenhower to George W. Bush took control of the Republican Party and used it instrumentally to advance his personal political purposes while simultaneously investing in its

17 Galvin, Presidential Party Building; Krimmel, "The Efficiencies and Pathologies of Special Interest Partisanship."

18 Ronald Reagan appears to be the sole exception. For a compelling explanation for Reagan's distinctiveness, consider Stephen Skowronek's argument that Reagan's moment in "political time" afforded him unusually strong political "authority to consolidate a coalition" to "support the new agenda and dominate electoral politics." Stephen Skowronek, Presidential Leadership in Political Time: Reprise and Reappraisal (2nd edition), (Lawrence: University Press of Kansas, 2011), p. 97. 
organizational capacities. ${ }^{19}$ Importantly however, these tactics were undertaken with a particular goal in mind: to build a durable new Republican majority that would reflect and perpetuate their political vision after they left office.

These presidents were not being altruistic in building their party. But neither were they driven completely by self-interest. They did not ruthlessly exploit their party for personal gain, nor did they build their party to operate without regard for their personal political ambitions. Their efforts were geared toward creating a new and different kind of party - one that would blend the responsiveness of a modern presidential campaign committee with the kind of organizational vibrancy and structural durability characteristic of nineteenth-century parties. They aimed to "presidentialize" their party, to make it more responsive to their leadership and more reflective of their personal brand of politics, but at the same time, they sought to strengthen its organizational foundations and enhance its capacities to expand and grow in the future. In other words, the six Republican presidents who served between 1953 and 2009 treated the GOP as central and consequential, not peripheral or detrimental, for themselves and others. The main ingredients of their party leadership included party domination and personalization, organizational investment, and majority-building through outreach to new groups.

\subsection{Domination and Personalization}

Like Trump, previous Republican presidents installed loyalists in key organizational leadership positions, set party policy from the White House, and tried to muffle dissent within the ranks. They, too, took control of their party's operations and insisted that its organizational apparatus be used to champion their agendas. They also sought to remake their party in their image by reconfiguring its electoral coalition and group alliances to better reflect their personal brand of politics. Recall that Eisenhower, Nixon, Ford, Reagan, Bush Sr., and even George W. Bush were all significantly more popular than the Republican Party, which was in the minority in Congress, at the state level, and among party identifiers in the electorate for almost the entire second half of the 20th century. In that context, dominating, personalizing, and expanding the party appeared to be complementary and logically consistent components of the same overarching party leadership project. The difficulties they experienced in trying to maintain control of their party while aggressively expanding its reach, however, were unexpected.

19 This section and the next draw upon Galvin, Presidential Party Building: Dwight D. Eisenhower to George W. Bush (2010). 


\subsection{Organizational Investment}

These presidents paired their efforts to personalize and control the party with constructive, top-to-bottom investments in the party's organizational capacities. They invested in their party's internal systems, communications capacities, and data infrastructure; worked to recruit, train, and mobilize new generations of activists, volunteers, and campaign operatives; enhanced their party's capacity to conduct massive voter registration drives; developed new fundraising systems and lent their prestige to help fill the party's coffers; made constructive investments in state and local party organizations; intervened in candidate recruitment and helped the party develop rigorous leadership development programs; and worked to equip the party to support complex electoral campaigns up and down the ballot, coordinate thousands of get-out-the-vote drives on election day, and more. These investments typically worked to the benefit of down-ballot Republican candidates as well as the president, likely contributing to the Republican Party's incremental electoral gains between the 1950s and early 2000s at all levels of government.

Perhaps the best illustration of how Republican presidents combined party domination, personalization, and organizational investment involved their reelection campaigns - the "main event" of American politics. Giving the party organization a central role in their campaigns provided the party with valuable opportunities to build and continually refine troves of data on voters and donors, invest in the party's human resources, experiment with new strategies, learn from mistakes, and make improvements for future campaigns. It gave the party a chance to get regular "exercise," if you will. Thanks in part to their consistent use of and investment in their party organization, the GOP was able to withstand myriad political setbacks. Even when they suffered personal political failures (Gerald Ford and George Bush Sr.) or epic collapses (Richard Nixon and George W. Bush) - these Republican presidents left their party in better organizational shape than when they inherited it.

Each new round of organizational party building created conditions that incentivized further party building in the future. Investments in human resources, data, and technological capacities, in particular, were self-reinforcing, helping to propel party-building initiatives over time despite changes in party leadership and personnel. ${ }^{20}$ With ongoing programs on which to build and low start-up costs, future presidents and out-party RNC chairs found it in their interest to continue down the party-building path. This was certainly the case for Donald Trump, who,

20 Daniel J. Galvin, "The Transformation of Political Institutions: Investments in Institutional Resources and Gradual Change in the National Party Committees," Studies in American Political Development 26 (2012): 50-70. 
upon securing the Republican nomination for president in 2016, became the lucky beneficiary of an organizationally robust party organization that had developed a "data and voter contact program that was really plug-and-play ready for the next candidate,” Trump's digital media director (and 2020 campaign manager) Brad Parscale said. ${ }^{21}$

\subsection{Majority-Building}

All of these efforts were geared toward - but also complicated by - their hopes of building a new Republican majority in their image. To forge a new majority that would be able to perpetuate their purposes long after they left the White House, these presidents developed programs at the RNC and through the White House Office of Public Liaison to reach out to new groups and voters in new geographies. ${ }^{22}$ Although they often made headway in incorporating new groups, one of the most conspicuous aspects of their majority-building efforts was how little they benefitted the presidents personally. None of their operationally successful partybuilding initiatives kept opponents at bay or protected the presidents from political crises that undercut their political standing. New leaders within the Republican Party, empowered by party-building efforts, often ended up taking control of the party and moving it in directions the presidents never intended for it to go.

Dwight Eisenhower, for example, aimed to transfer his enormous personal popularity onto the Republican Party, remake it into what he called a "Modern" Republican Party, and give it the wherewithal to promote his "middle of the road" policy agenda while winning support in every region of the country. In one of his more notable efforts to expand the party's reach, Eisenhower launched "Operation Dixie," the Republican Party's first formal effort to expand into the South after the New Deal. Eisenhower hoped to reach out to moderates, young urban professionals, less racist suburbanites, and African Americans and build an organizational foundation for the party's further growth in that region. ${ }^{23}$ The particular coalition he envisioned was never realized, however, and Eisenhower's efforts inadvertently laid the groundwork for the GOP's rightward turn under Barry Goldwater and the racial backlash-centered "Southern Strategy" under Nixon.

Richard Nixon, too, sought to use the Republican Party to build his own vision of a "New Majority" based on his landslide 1972 electoral coalition. Despite his

21 Kate Kaye, "How the Trump Camp's Data Inexperience Helped Propel his Win,” AdAge, December 14, 2016.

22 On the development of the OPL, see Krimmel, "The Efficiencies and Pathologies of Special Interest Partisanship.”

23 Galvin, Presidential Party Building, 63-67. 
short-lived second term, Nixon successfully launched a broad-based partybuilding program at the RNC to recruit new candidates, teach new campaign management techniques, and reach out to what he called "New Majority" groups (which included "ethnic voters, Spanish speaking voters, senior citizens, youths, blacks, and the blue collar laborers," as well as "Sons of Italy," rank-and-file union members, labor leaders, and Southerners). ${ }^{24} \mathrm{New}$ party programs were undertaken explicitly for this purpose: a series of "New Majority Workshops" across the country to share best practices for appealing to "special voter groups"; a new "Campaign Management College"; training for thousands of activists on voter mobilization; RNC task forces to bolster state parties; and more. Nixon's organizational party-building achievements, however, did little to prevent his fellow Republicans from abandoning him amid the fallout from the Watergate scandal.

Gerald Ford thus inherited an electorally devastated party that was nevertheless quite active and energetic at the organizational level. Picking up where Nixon left off, he continued to sponsor grassroots party-building programs to get the "New Majority" ball rolling again and supported outreach programs to attract young voters, Southerners, "ethnics," African Americans, Hispanics, and urban residents to the GOP. "If we are going to broaden the base of the party," Ford said, "to make the politics of addition - instead of subtraction - work, we must commit ourselves again and again to accommodation, conciliation and cooperation - not to mention hard work." ${ }^{25}$ Although Ford was among the most tireless and programmatically successful party builders and the first to fully institutionalize partygroup relations in the White House by forming the White House Office of Public Liaison, ${ }^{26}$ conservatives, especially in the South - empowered by two decades of concerted efforts to build the Republican Party in the region - nearly cast him aside in the 1976 nomination contest in favor of Ronald Reagan, leaving him politically weakened heading into the general election.

Ronald Reagan, much like Eisenhower and Nixon, sought to translate his broad electoral support among Republicans, Independents, and "Reagan Democrats" into a new and enduring majority for the Republican Party. Although Reagan had long argued that "a political party cannot be all things to all people," 27 he leveraged his broad popularity to reach out to blue-collar workers, Evangelicals, white Southerners, "urban ethnics," and middle-class suburbanites, and tried to persuade them to join the Republican coalition along with Wall Street bankers, businessmen, rural farmers, and small business owners. African Americans were

24 Galvin, Presidential Party Building, 92, 96.

25 Ibid., 115.

26 Krimmel, "The Efficiencies and Pathologies of Special Interest Partisanship”.

27 Galvin, Presidential Party Building, 115. 
conspicuously ignored. Through a formal party initiative titled "Operation Open Door” (remarkably, the same term used by Eisenhower, Nixon, and Ford to describe their party outreach efforts), ${ }^{28}$ Reagan sought to recruit Democrats to switch to the GOP; he and his team also invested heavily in new voter registration programs and worked to bolster Republican county party organizations. ${ }^{29}$ Reagan's party-building efforts were integral to his reconstructive ambitions; notwithstanding his second-term political scandals, Reagan was clearly the most politically successful Republican president of the modern era. ${ }^{30}$

Hoping to build on Reagan's party-building gains and capitalize on the decennial reapportionment process to level the playing field in 1991, George H. W. Bush redoubled the party's commitment to building a new majority by strengthening state party organizations, winning state legislative and gubernatorial offices, and making further inroads in the South. Bush and his team also launched "Operation Switch" to convince local elected Democrats to become Republicans and carried out a series of programs dedicated to reaching out to African Americans. Party building, for Bush, was how the Republican Party would "become the majority party in America” within a decade. But his efforts to expand the party strained tensions with recently incorporated groups. For example, when Bush and his RNC chairman Lee Atwater called the GOP an "umbrella party” and announced there would be no litmus test for Republican candidates on abortion rights, they drew the ire of the social conservatives now firmly ensconced in the GOP; likewise, supporting new taxes to appease deficit hawks (after famously pledging "no new taxes") infuriated newly emboldened supply siders. ${ }^{31}$ Groups that both Reagan and Bush had earlier wooed now challenged Bush's efforts to put his own stamp on the party and sought to thwart his renomination in 1992. Although Bush made valuable contributions to the Republican Party's organizational development, his party coalition-building efforts undercut his ability to control the party and left him politically damaged.

Despite the GOP's improved electoral position in the early 21st century, George W. Bush and his team echoed the goals of earlier Republican presidents in seeking to build a "permanent Republican majority" that would finally "reverse the course set 70 years ago by President Franklin D. Roosevelt."32 Under Bush, the Republican Party launched programs to reach out to African Americans, Latinos, Catholics,

28 Ibid., 53, 56, 82, 83, 87, 113, 114, 114, 116, 136-138.

29 Ibid., ch. 6. Also see Benjamin Ginsberg and Martin Shefter, "The Presidency and the Organization of Interests," in The Presidency and the Political System, ed. Michael Nelson. Washington, DC: Congressional Quarterly Press, 1988.

30 Skowronek, Presidential Leadership in Political Time, p. 97.

31 Galvin, Presidential Party Building, p. 152.

32 Ibid, 255. 
Asians, Jews, and middle-class voters more seriously than in the past. Bush's handpicked chair of the RNC, Ken Mehlman, announced at the start of Bush's second term that "GOP must continue to stand for Grow Our Party" and began to aggressively sell Bush's “Ownership Society” agenda to minority groups while recruiting nonwhite Republicans to run for office. An "outreach series” was created to appeal to Jews and Hispanics, as were new "advisory committees" to incorporate Latino and Black community leaders into the party's higher councils - likely an effort to consolidate the gains Bush made with Latinos in the 2004 election. ${ }^{33}$ As was the case for most of his predecessors, however, these outreach efforts were rejected by groups that had by now become core constituencies of the GOP, leading to charges of betrayal and more aggressive efforts to move the party in a very different direction (i.e. Sarah Palin, the Tea Party).

Until Trump, in other words, Republican presidents repeatedly acted out a similar script, dominating and personalizing their party and investing in its organizational capacities for the explicit purpose of majority-building and coalition-expansion. But their tactics and strategies were rarely complementary and often worked at cross-purposes: their outreach efforts tended to undercut their ability to control the party and remake it in their image and their personalization efforts often backfired. Yet their behavior constituted a remarkably consistent pattern of presidential party leadership that shaped the GOP's organizational trajectory over the course of almost 60 years. The best way to appreciate Trump's relative "fit" within this pattern is to compare the typical Republican approach to the alternative pursued by Democrats during the same time period.

\section{Party Asymmetry: Democratic Presidents Since Kennedy}

Although Democratic presidents also asserted control over their party organization, installed loyalists in key positions, and directed party operations from the White House, their approach differed significantly from their Republican counterparts. Crucially, they did not make significant investments in their party's organizational capacities. From Kennedy to Obama, Democratic presidents consistently neglected, exploited, or undermined their party. Whereas Republican presidents almost always gave their party a central role in their reelection campaigns (Nixon was the sole exception), Democratic presidents routinely circumvented their party, building alternative party-like organizations to run their

33 Ibid., 255-259. 
campaigns independently of the party. They shunted the formal party apparatus to the sidelines, plundered its financial resources, hoarded its information assets, and left it to atrophy. Kennedy, Johnson, Carter, Clinton, and Obama left it to others - usually the incoming chairs of the Democratic National Committee - to dig the party out of debt and/or build new organizational capacities from scratch. ${ }^{34}$

Although Obama made a few constructive investments in his party organization in his second term, those efforts were minimal and could not compensate for years of neglect. ${ }^{35}$ In fact, the bulk of his efforts to build a political organization took place outside the formal party structure. Rather than invest in the Democratic Party, Obama launched a wholly separate 501(c)(4) nonprofit organization (Organizing for Action) which "hoarded" his campaign's key data on small donors, volunteers, and activists; created confusing lines of authority; cost the party valuable time in sorting out the division of assets, personnel, and mission; and ultimately left the formal party and down-ballot Democrats with little more than scraps from Obama's 2012 massive, data-driven presidential reelection campaign. $^{36}$ The Democratic nominee in 2016, Hillary Clinton, claimed that her campaign "inherit[ed] nothing” from the DNC and reported that the party was "on the verge of insolvency, its data was mediocre to poor, non-existent, wrong." 37 Although some party personnel quarreled with her account, Obama acknowledged toward the end of his presidency that he did not do enough to build the Democratic Party. "Partly because my docket was really full here, so I couldn't be both chief organizer of the Democratic Party and function as commander in chief and president of the United States," Obama admitted. "We did not begin what I think needs to happen over the long haul, and that is rebuild the Democratic Party at the ground level." 38

As Obama's quote indicates, Democratic presidents in the post-New Deal era focused almost exclusively on governing, seeking to create a policy legacy rather

34 Philip A. Klinkner, The Losing Parties: Out-Party National Committees, 1956-1993 (New Haven: Yale University Press, 1994). Galvin, Presidential Party Building.

35 Daniel J. Galvin, “Obama built a policy legacy. But he didn't do enough to build the Democratic Party,” The Washington Post - Monkey Cage, November 16, 2016; Gabriel Debenedetti, “Obama’s party-building legacy splits Democrats," Politico, February 9, 2017.

36 Ibid. For a more nuanced view of the costs and benefits of Obama's decision to launch OFA rather than build the Democratic Party, see Sidney M. Milkis and John Warren York, "Barack Obama, Organizing for Action, and Executive-Centered Partisanship," Studies in American Political Development 31 (2017): 1-23.

37 MJ Lee, “Clinton slams New York Times, DNC, Comey for her loss," CNN Politics, May 31, 2017. 38 Chris Cillizza, "President Obama finally admitted he didn't pay enough attention to the Democratic Party,” The Washington Post, January 9, 2017. 
than a party-building legacy. ${ }^{39}$ As a large, heterogeneous "big tent" majority party, their primary challenge was to persuade their fellow Democrats in Congress to support their policy goals - a task that required more personal persuasion than long-term organization-building. Richard Neustadt famously defined the central challenge of presidential leadership in precisely these terms: as a struggle to enhance the president's "personal capacity to influence the conduct of the men who makeup government." 40 This was certainly how Democratic presidents saw things when Democrats held both houses of Congress. To be sure, they often found their party's friendly majorities less friendly, and unified government less unified, than they had hoped. But rather than dismantle an imperfect majority and build a new one in its place, they tried to make the most of the party majorities they inherited. After Democrats lost their congressional majorities in Clinton's and Obama's first terms, both Democratic presidents began to change their approach, making several constructive investments. But their smattering of party-building efforts was too little, too late: years of organizational neglect had raised the startup costs of new initiatives and made cumulative organizational development in the party more difficult.

\section{Trump's Party Building}

Like his Republican predecessors, Trump has established a commanding influence over his party - some have even likened it to a "cult of personality" ${ }^{41}$ - while also making constructive investments in its organizational capacities. In these respects, his efforts look like the traditional Republican approach to party building "on steroids." He has diverged from past patterns, however, in thus far choosing to focus more on base-mobilization than outreach and majority-building. ${ }^{42}$

Before exploring these aspects of Trump's party leadership in greater detail, it is worth noting that there is no commonly agreed upon definition of the president's “base.” Some use the term to refer to Trump's 2016 electoral coalition. Others use it

39 Daniel J. Galvin and Chloe N. Thurston. 2017. "The Democrats' Misplaced Faith in Policy Feedback," The Forum 15 (2): 333-344; and see updated version: Daniel J. Galvin and Chloe N. Thurston, "The Limits of Policy Feedback as a Party-Building Tool," in American Political Development and the Trump Presidency, Philip Rocco and Zachary Callen, eds. (Philadelphia: University of Pennsylvania Press, 2020).

40 Richard Neustadt, Presidential Power (New York: Wiley, 1960), 4.

41 Sean Illing, "Is Trumpism a cult?: A new book from a former cult member makes the case," Vox, December 13, 2019.

42 Notably, Trump has not mentioned the concept of majority-building (variously phrased) since his inauguration in either his Tweets or recorded public speeches. 
to mean poll respondents who report strong support for the president. Still others use it to describe high-propensity voters and activists who are most enthusiastic about the president as they look to the 2020 election. Often, the term is used to draw a distinction between Trump's core supporters and self-identified Republican voters. Although any of these definitions work equally well for our purposes here, it is worth pointing out the fallacy of the latter claim.

As it turns out, Trump's base does not differ much from the base of the Republican Party that emerged during Obama's presidency, prior to Trump's nomination. The dominant media narrative that Trump brought an influx of new working-class whites into the Republican coalition through his anti-immigrant, xenophobic, nationalistic rhetoric and policy positions does not hold up under scrutiny. For example, in their book Identity Crisis, John Sides, Michael Tesler, and Lynn Vavreck find that Trump's anti-immigrant rhetoric and policies "tapped into beliefs, ideas, and anxieties that were already present and even wellestablished within the party. His support was hiding in plain sight." 43 Larry Bartels similarly finds that "the rise of Trump seems to have had surprisingly little impact on the actual composition of the Republican and Democratic parties." Citing Sides, Bartels notes that "the much-noted migration of "workingclass' whites to the Republican Party 'mainly occurred from 2009 to 2015." "44 In this light, Trump appears as more of a symptom than a cause of the changing Republican base. Further, Bartels finds precious few party switchers between 2015 and 2017 (and Republican-to-Democrat switchers were actually slightly more numerous than Democrat-to-Republican switchers). Nor did Trump draw a disproportionate number of new voters into the electorate: exit polls show firsttime voters in 2016 breaking for Clinton 57-38\%. ${ }^{45}$ Trump's base-mobilization strategy, in short, is virtually indistinguishable from a Republican Partymobilization strategy. ${ }^{46}$

43 John Sides, Michael Tessler, and Lynn Vavreck, Identity Crisis: The 2016 Presidential Campaign and the Battle for the Meaning of America (Princeton: Princeton University Press, 2018), 95-96.

44 Larry M. Bartels, "Partisanship in the Trump Era," The Journal of Politics 80, 4: 1492-1493. Bartels' cite is to John Sides, "Race, Religion, and Immigration in 2016: How the Debate over American Identity Shaped the Election and What It Means for a Trump Presidency,” Democracy Fund Voter Study Group, June 2017.

45 https://www.cnn.com/election/2016/results/exit-polls.

46 Relatedly, see Christopher Baylor, "The Post-Trump GOP Looks a Lot Like the Pre-Trump GOP," Vox, April 6, 2018; Julia Azari, "Can a Maverick Candidate Save the Republican Party?: Transforming a Political Party is Harder Than It Looks,” Vox, March 2, 2018; Matt Grossmann and David A. Hopkins, “Trump Isn't Changing the Republican Party. The Republican Party is Changing Trump,” The Washington Post-Monkey Cage, August 2, 2017. 


\subsection{Domination and Personalization}

The first and most conspicuous characteristic of Trump's party leadership is captured well in the title of the recent New York Times article, "Fear and Loyalty: How Donald Trump Took Over the Republican Party." 47 Whereas Trump's Republican predecessors tended to use persuasion and sub-rosa pressure tactics to get fellow party members to fall in line, Trump has publicly and combatively demanded fealty from all Republicans. He uses his Twitter megaphone to bully dissenters, stirs up his base to hound those who stray from the party line, and retaliates against defectors by endorsing and campaigning on behalf of primary challengers. ${ }^{48}$ Trump wields the carrot effectively, too: Republicans at all levels of government lavish the President with praise capturing his attention and winning his valuable endorsement. ${ }^{49}$ Trump also rewards Republican members of Congress who remain loyal to him by setting up joint fundraising committees and "tapping his vast fundraising network" to solicit donations for their reelection campaigns. ${ }^{50}$

But it is the threat of Trump's wrath and the potential to win his endorsement that may have extended his reach the farthest, enabling him to remake the party without having to do anything at all. With Trump and his team on the lookout for any signs of defection, Republican candidates understand that their only realistic choices are exit or loyalty. Consequently, would-be dissenters have either fallen in line, retired, or been defeated, leaving behind only the most devoted supporters of the president. ${ }^{51}$

According to Democratic Senator Sherrod Brown, "fear is the motivator" behind his Senate Republican colleagues' loyalty to Trump. But Brown also notes that this fear operates in a broader context in which a devoted Republican activist

47 Jonathan Martin and Maggie Haberman, "Fear and Loyalty: How Donald Trump Took Over the Republican Party,” The New York Times, December 21, 2019.

48 Jonathan Martin and Alexander Burns, "Trump Endorsement in Georgia Race Surprised, and Frustrated, Some Republicans,” The New York Times, July 20, 2018.

49 Jonathan Martin, "In Florida, Not All Politics Are Local, as Trump Shapes Governor's Race," The New York Times, July 30, 2018.

50 Alex Isenstadt, “Trump lures GOP senators on impeachment with cold cash," Politico, October 31, 2019; Karl Evers-Hillstrom, "Trump launches joint fundraising committee with vulnerable GOP senator,” OpenSecrets.org, November 1, 2019.

51 Martin and Haberman, "Fear and Loyalty: How Donald Trump Took Over the Republican Party”; Jonathan Martin, "In Florida, Not All Politics Are Local, as Trump Shapes Governor's Race,” The New York Times, July 30, 2018; Evers-Hillstrom, “Trump launches joint fundraising committee with vulnerable GOP senator.” The day after his Senate impeachment trial acquittal, the New York Times editorial board remarked that the Republican Party was "morphing into a cult of personality.” The Editorial Board, "What Will Finally Defeat Donald Trump?,” The New York Times, February 5, 2020. 
base and a network of outside institutions and organizations magnify and reinforce Trump's influence:

\begin{abstract}
"They are afraid that Mr. Trump might give them a nickname like "Low Energy Jeb” and "Lyin' Ted," or that he might tweet about their disloyalty. Or - worst of all - that he might come to their state to campaign against them in the Republican primary. They worry: "Will the hosts on Fox attack me?" "Will the mouthpieces on talk radio go after me?" "Will the Twitter trolls turn their followers against me?" My colleagues know they all just might." ${ }^{22}$
\end{abstract}

The source of Trump's power thus lies not in his mastery of political hardball, per se, but rather in the reliable support he receives from devoted Republican voters and the broader conservative organizational ecosystem, both of which back up Trump's threats with real consequences.

Republican Representative Patrick McHenry similarly noted that Trump "touched the nerve" of his conservative base and enjoyed a "complete connection" with self-identified Republicans, whose already strong support for the President actually grew in each of his first three years in office (averaging 83, 87, and 89 percent per year, 2017-2019). ${ }^{53}$ Trump's support from the Republican electorate is reinforced and amplified by the $24 / 7$ backing he receives from right-wing media and major elements of the "Republican/conservative organizational universe" that have thrived off of Trump's controversial presidency. ${ }^{54}$

In the context of extreme partisan polarization, the vigorous and dependable support Trump receives from the Republican rank-and-file and the right-wing institutional support structure provides him with a "coat of armor" that all of his predecessors, even the most successful ones (Reagan, Eisenhower) lacked. ${ }^{55}$ The political protection he derives from this support does not, of course, mean that Trump's individual policy choices will always go unchallenged by members of his party. Indeed, by conventional measures of the president's ability to accomplish his policy objectives, Trump actually appears quite weak, as political scientist Matt

52 Sherrod Brown, "In Private, Republicans Admit They Acquitted Trump Out of Fear,” The New York Times, February 6, 2020.

53 "Complete connection" is from Martin and Haberman, "Fear and Loyalty"; Gallup, "Presidential Approval Ratings - Donald Trump,” https://news.gallup.com/poll/203198/presidentialapproval-ratings-donald-trump.aspx.

54 Jeffrey M. Berry and Sarah Sobieraj, The Outrage Industry: Political Opinion Media and the New Incivility (Oxford University Press, 2013); Igor Derysh, "Trump sycophancy pays off as Fox News earns highest ratings in network's 23-year history,” Salon, December 30, 2019; Theda Skocpol and Alexander Hertel-Fernandez, "The Koch Network and Republican Party Extremism," Perspectives on Politics 14 (2016): 681-699.

55 Jonathan Martin and Maggie Haberman, "Fear and Loyalty." 
Glassman has pointed out. ${ }^{56}$ But there can be little doubt that Trump has been shielded from more fundamental challenges to his authority. Trump's partybuilding efforts have enabled him to tap into the deep well of extreme partisanship and exploit it for his own purposes, which has provided him cover for his abuses of power and more questionable judgment calls (the latter point is elaborated further in the final section below).

Trump has also taken advantage of the authority presidents traditionally wield over their formal party organizations. This authority is not new - every president since Eisenhower exercised nearly absolute control over the national committee and set the party's strategic and operational priorities from the White House. As political scientist Boris Heersink noted, this is largely due to the longstanding tradition in which presidents have free rein to hand-pick a loyalist to fill the role of national party committee chair (a choice that is then rubber-stamped by the RNC). Trump has leveraged this influence to "use the RNC to promote the GOP as 'his' party," Heersink writes, and to provide jobs for campaign personnel and other Trump loyalists through the RNC. ${ }^{57}$ His hand-picked RNC chair, Ronna Romney McDaniel, routinely enforces discipline within the party with warnings like the one she issued after Trump critic Mark Sanford was defeated in his congressional primary by a Trump loyalist: Those who do not “embrace” Trump's MAGA agenda, she tweeted, "will be making a mistake." ${ }^{58}$ Heersink also notes that presidents can use their authority over the RNC to influence the nomination process: They can alter the primary calendar, affect the distribution of delegates by state, determine the timing and form of primary debates, and plan the national convention - all useful mechanisms for fending off potential intraparty challenges and insuring the president's renomination.

Trump and his team have also methodically reshaped state party organizations in dozens of states. "A small but ferocious" team of staffers led by White House Political Director Bill Stepien and White House Director of Public Liaison Justin Clark has traveled around the country intervening in state party chair elections to insure that Trump's favored candidates won. "We are monitoring, tracking, and ensuring the president's Allies are sitting at the top of state parties,"

56 Matt Glassman, “The Root of White House Chaos? A Weak President," The New York Times (Opinion), March 1, 2018; Matt Glassman, "How Republicans Erased Trumpism,” The New York Times (Opinion), February 1, 2019.

57 Boris Heersink, "Trump and the Party-in-Organization: Presidential Control of National Party Organizations,” The Journal of Politics 80 (2018): 1474-482.

58 Brett Samuels, “GOP chairwoman: Anyone who doesn't support Trump 'will be making a mistake',” The Hill, June 13, 2018. 
acknowledged Stepian in early 2019. ${ }^{59}$ By the end of 2019, Trump loyalists had reportedly been installed in the top spot in 42 states, and the state parties were described as thoroughly "remade" in "the president's image."60 The state party chair in Florida, for example, serves concurrently as the state chair of the Trump campaign, and the state Republican Party organization has become "effectively a regional arm of the president's re-election effort."61

In part, Trump and his team have targeted state party chairs because they hold the keys to the president's renomination. Canceled primaries in five states have drawn the most media attention, but arguably more important are the 37 states and territories where Trump's team convinced state parties to alter their delegate allocation plans - how they select and constrain the delegates they send to the national convention - to "all but stamp out the possibility of any raucous divide on the convention floor." As a result, the two peripheral Republicans running against Trump stand little chance of forcing their way onto the convention stage. ${ }^{62}$

More important, however, is the state party chairs' ability to shape the channels of advancement within the party. This is where Trump has managed to remake the party from the inside out. Through the quiet politics of within-state candidate recruitment, Trump's loyal state party chairs are able to insure that only vocal, committed Trump supporters are recruited to run for office and receive the state party's valuable services and support. ${ }^{63}$ State chairs make many varied logistical decisions that can influence the type of Republicans who run for office and shape their probability of winning: they coordinate the state party's fundraising activities and determine its spending priorities; they send paid staff to assist with certain campaigns rather than others; they sponsor activist recruitment and volunteer training programs in certain geographic areas rather than others; and they make myriad other decisions that shape the context of primary and general election

59 Alex Isenstadt, “Trump campaign moves to stave off mayhem at 2020 convention,” Politico, January 7, 2019.

60 Jonathan Swan and Margaret Talev, "How Trump wins in 2020,” Axios, December 14, 2019; Joe Walsh, "Republicans Suppress Their Own Voters," The Wall Street Journal opinion, December 5, 2019.

61 Alexander Burns and Jonathan Martin, “Trump’s Takeover of the Republican Party Is Almost Complete,” The New York Times, April 3, 2019.

62 Maggie Haberman and Annie Karni, "Republicans Changing Delegate Rules to Prevent Discord at Convention," The New York Times, October 2, 2019.

63 See, e.g. Fred Mogul, "Diehard Trump Supporter from Erie Takes Control of NY State Republican Party," Gothamist, May 21, 2019; Kathleen Ronayne, "NH Republicans choose Forrester to lead state party," Fosters, January 28, 2017. On the more general tendency of local party leaders, especially Republicans, to recruit extremist candidates, see David E. Broockman, Nicholas Carnes, Melody Crowder-Meyer and Christopher Skovron, “Why Local Party Leaders Don't Support Nominating Centrists,” British Journal of Political Science (2019): 1-26. 
campaigns. In other words, by personalizing state party organizations, Trump has secured the ability to control some of the basic functions of political parties: regulating access to elective office, managing competition between aspirants, and channeling office-seekers' ambition. ${ }^{64}$

In short, through his heavy-handed approach to dealing with elected Republicans and party organization leaders, Trump has increased his influence over his fellow partisans at the national, state, and local levels. This has been reinforced and solidified through Trump's investments in the party's massive fundraising operations, its extensive data collection and analysis operation, and its humanresource development programs, as detailed below.

To repeat, none of this means that congressional Republicans are unable or unwilling to push back against Trump's behavior or policy decisions on specific issues. This happened periodically throughout Trump's first term and will surely continue. Republican Senators, for example, have bucked the president on highsalience issues like the president's confrontation with Iran in early 2020, and members of the House Liberty Caucus have periodically struck a defiant tone on deficit spending, arguing for greater fiscal restraint. ${ }^{65}$ But public confrontations have been few and far between, and Trump's leadership authority within the party has remained remarkably resilient. While divisive issues that generate public dissent from Republicans will undoubtedly continue to emerge, the main storyline of Trump's party leadership through early 2020 has been his domination and personalization of the Republican Party.

\subsection{Organizational Investment}

Upon securing the Republican nomination for president in 2016, Trump inherited a well-oiled Republican Party apparatus that boasted robust, up-to-date data and voter contact programs that were already in operation. ${ }^{66}$ With his own operation woefully disorganized and ill-equipped to coordinate a national campaign, Trump relied heavily on the existing Republican party organization to run his general election campaign. In so doing, Trump provided the party with exactly the kind of vigorous workout that has historically redounded to its organizational benefit while reducing the costs of making further investments in the near future. After the election, Trump quickly installed loyalists in positions of party leadership and

64 John H Aldrich, Why Parties?: A Second Look (University of Chicago Press, 2011), 19-20.

65 Veronica Stracqualursi, "Trump rails against GOP congressman who signaled support for forcing roll-call vote on coronavirus stimulus deal,” CNN, March 27, 2020.

66 Reince Priebus, "Reince Priebus: RNC was the data firm of the Trump campaign,” CNBC, March 20, 2018. 
continued to invest in its organizational capacities in preparation for the 2020 reelection campaign.

During Trump's first two years in office, political scientist Brendan Doherty found that the president focused more on raising money for himself than for fellow Republicans - as one might expect when the president's party controls both houses of Congress. ${ }^{67}$ But after Republicans lost control of the House of Representatives in the 2018 elections, Trump's behavior changed and the joint TrumpRNC fundraising operation began funneling millions of dollars into state party committees to support congressional races and state-level elections. ${ }^{68}$ The joint committee also ran negative ads in the districts of vulnerable Democrats and launched an innovative new digital fundraising tool called WinRed to raise and distribute funds broadly to down-ballot Republican candidates, explicitly seeking to replicate the success of the Democratic platform ActBlue. ${ }^{69}$ As the 2020 campaign got underway, the RNC took the lead on fundraising, including digital efforts, prospecting for new donors, and hosting major fundraising events. Combined, the Trump campaign and the RNC raised $\$ 463$ million by the end of 2019 and had almost $\$ 200$ million cash on hand at the start of $2020 .^{70}$

The campaign also made major investments in the party's human capital. By the end of 2019, the party was on its way to training 60,000 "fellows" to coordinate a 2-million strong "volunteer army" to undertake grassroots voter registration, activist recruitment, and get-out-the-vote activities, using both social media and door-to-door canvassing to mobilize Trump's base. ${ }^{71}$ Trained volunteers used "dynamic scripting" to microtarget groups of potential Trump voters with differentiated, tailored messages for core voters, "disengagers," and nonvoters, using regularly refreshed data on "what they do, where they shop, where they eat, where

67 Anita Kumar and Ben Wieder, “Trump raised \$135 M at 29 fundraisers. But nearly half the events were for himself,” McClatchy, August 7, 2018; Galvin, Presidential Party Building, ch. 2.

68 Yue Stella Yu, "RNC continues to dwarf DNC in fundraising," Opensecrets.com, October 21, 2019.

69 Josh Dawsey and Michelle Ye Hee Lee, “Trump and the RNC raised almost half a billion dollars last year - and still had nearly \$200 million heading into 2020," The Washington Post, January 3, 2020; Bill Allison, “Trump Launches GOP’s New Digital Fundraising Tool to Help Party Down Ballot,” Bloomberg, June 24, 2019; https://twitter.com/realDonaldTrump/status/1143159975277187072?s=20; Carrie Levine, "Red Shift: How Republicans Plan To Catch Democrats In Online Fundraising," NPR, July 1, 2019; Danny Hakim and Glenn Thrush, "How the Trump Campaign Took Over the G.O.P.,” The New York Times, March 9, 2020.

70 Annie Karni and Maggie Haberman, “Trump and R.N.C. Raised \$105 Million in 2nd Quarter, a Sign He Will Have Far More Money than in 2016,” The New York Times, July 2, 2019.

71 Max Greenwood, “Trump campaign, RNC training army of volunteers in key 2020 states," The Hill, July 19, 2019; Tamara Keith, "With Voter Data and a Volunteer Army, A Whole New Trump Campaign For 2020,” NPR, June 27, 2019. 
they exercise" to deliver individualized messages. ${ }^{72}$ The Trump-RNC campaign operation also sent 400 paid staff to 18 battleground states and was in the process of sending 300 more just prior to the COVID-19 outbreak. ${ }^{73}$ Campaign staffers "had already knocked on a million doors" prior to the pandemic, however, and had ramped up their efforts to boost the fortunes of all Republican candidates. Party officials noted that "canvassers would be promoting GOP candidates up and down the ballot."74

In conjunction with Trump's efforts to remake state parties in his image, regulate intraparty competition, and shape the party's candidate recruitment processes, these and other organization-building efforts have provided Trump with a valuable set of tools with which to further augment his power over elected officials in the party.

\subsection{Base Mobilization}

By early 2020, Trump's top priorities were clear: agitate, energize, and mobilize his most enthusiastic supporters to volunteer for the campaign and vote Republican; enlist them to recruit others to do the same; register those who were first-time or low-propensity voters as Republicans; and depress Democratic turnout. The "bet" was that "a fired-up base" would be enough to "offer him a narrow but genuine path to a second term."75

Party leaders understood that Trump's divisive personality, provocative statements, and extreme policy stands were likely to energize the Democrats' base as well - but the campaign wagered that Trump's hyper-mobilized base would more than offset any Democratic gains. At the time of this writing, the campaign was hoping that Trump would outperform his polling numbers (which they viewed as artificially low due to respondents' reluctance to admit they support Trump) in key states by several percentage points and that its "voter ID-mobilization-andturnout operation" would be "vastly better organized and staffed than what Democrats will be able to muster." 76 Although it seemed a risky strategy to focus so

72 A.B. Stoddard, "Dems Beware - the RNC is Crushing it," Real Clear Politics, October 25, 2019. 73 Josh Dawsey and Michelle Ye Hee Lee, "Trump and the RNC raised almost half a billion dollars last year,” The Washington Post, January 3, 2020.

74 Alex Isenstadt, "RNC will flood battleground states with staffers to boost Trump," January 23, 2020.

75 Stephen Collinson, "Donald Trump stokes fear and conspiracy on path to 2020," CNN, July 12, 2019.

76 John F. Harris, Alex Isenstadt and Daniel Lippman, "Why Trump's path to reelection is totally plausible," Politico, December 16, 2019. 
heavily on base mobilization, former Republican consultant Mark McKinnon opined that “it may be Trump's only possible route to victory. If he can't convert any Democrats or Independents, which a lot of polling suggests, then he'll have to rev up his base into a 100 percent turnout frenzy and make the Democratic nominee the greatest threat to democracy and keeping America great since, well, Hillary Clinton." ${ }^{\text {"7 }}$

Trump appears to have settled on this strategy early. By the spring of 2019, the RNC had begun to strategically hold Trump's large rallies in battleground states and use them to identify and mobilize attendees who were first-time or infrequent voters but supported the president. "These are new voters that we intend to bring into the Trump coalition,” explained Kayleigh McEnany, RNC national spokespersonturned-White House press secretary. With detailed data on these key voters vacuumed up at the rallies, the joint Trump-RNC campaign operation was planning to "use our historic army of volunteers to make contact with every voter necessary to ensure President Trump's re-election."78 According to one political analyst, the strategy was innovative: "Rather than build from his base, like a traditional politician, Trump is trying to expand his base and make it a larger share of the overall electorate."79

The campaign also sought to recreate Trump's 2016 coalition by winning back Trump voters who either failed to vote or voted for Democrats in the 2018 midterm elections - predominantly suburban women, upper income and college-educated whites, and independents. ${ }^{80}$ But among the campaign's various plans and programs, the lack of serious overtures to new groups was conspicuous. There was, of course, Trump's high-profile, almost over-the-top effort to demonstrate support for the African-American community in late 2019 and early 2020. Trump ran an \$11 million Super Bowl ad featuring an older African-American woman whose prison sentence Trump commuted after Kim Kardashian West lobbied the president on her behalf. ${ }^{81}$ The campaign also held several events and rented storefronts in swing states to sell merchandise and tout African Americans' economic gains during the

77 Myra Adams, “How GOP Insiders View Trump’s ‘Base-Only’ 2020 Strategy,” Realclearpolitics. com, June 28, 2019.

78 Jonathan Allen, “Inside Trump’s all-about-that-base 2020 strategy,” NBC News, April 8, 2019. 79 Ibid.

80 Maggie Haberman, Annie Karni and Jonathan Martin, “On Trump's To-Do List: Take Back the Suburbs. Court Black Voters. Expand the Electoral Map. Win.,” The New York Times, February 8, 2020.

81 Frank Miles, “Trump campaign prison reform Super Bowl ad features Alice Marie Johnson," Fox News, February 2, 2020; https://twitter.com/i/status/1224119370839994369. 
Trump presidency, including low unemployment, Trump's support for HBCUs, and criminal justice reform. ${ }^{82}$

Many scholars and observers interpreted these moves as indirect efforts to attract suburban white voters who were turned off by Trump's overt racial conservatism. According to political scientist Erin McDaniel, for example, the efforts were geared mostly toward "court[ing] whites who feel uneasy about the party's negative racial image." Others interpreted it as a "strategy of demobilization" - an effort to instill enough uncertainty in the minds of Black voters about Democrats that they would vote for a third-party candidate or stay home on election day, political scientist Matthew Platt explained. If enough African American voters were affected, it could make a difference at the margins in key swing states like Michigan, Pennsylvania, and Georgia. ${ }^{83}$

But even if one were to give the Trump-RNC operation the benefit of the doubt and treat the "Black Voices for Trump" effort as a sincere attempt to bring more African American voters into the Republican coalition, it would still appear to be the exception that proves the rule, as it were - so conspicuously different from the rest of Trump's campaign that it serves to highlight the predominance of the basemobilization strategy. Indeed, the message of outreach was seemingly contradicted by Trump's rhetoric at his large campaign rallies, where supporters were fed a "diet of red meat" and "culture war" rhetoric. ${ }^{84}$

Although a predominantly base-centered strategy may be irresistible for this particular president and rational given current levels of partisan polarization and the well-known challenges associated with trying to persuade nonvoters to vote, evidence was beginning to mount in early 2020 that it may not be the wisest strategy. Political scientists Laurel Bliss and Brian Schaffner, for example, found that 10 percent of voters who supported Trump in 2020 were "persuadable" "swing voters" who just might be decisive in 2020. But winning their votes could require different rhetorical appeals and more moderate policy stands than those used to mobilize Trump's more "dedicated" voters. ${ }^{85}$

82 Annie Karni and Maggie Haberman, "Trump Campaign Will Open Storefronts in Swing States to Reach Black Voters,” The New York Times, February 26, 2020; Ben Schreckinger, “Trump Allies are Handing out Cash to Black Voters," Politico, January 29, 2020.

83 Alex Isenstadt and Maya King, "Trump shocks black voters - by trying to get their votes," Politico, December 13, 2019; Morgan Chalfant and Brett Samuels, "Trump steps up pitch to black voters," February 9, 2020; Sara Weissmann, “Trump Touts Relationship with HBCUs with Eye on 2020," Diverse, October 28, 2019.

84 David M. Drucker, "GOP fears Trump 'election diet of red meat' will overshadow economy in 2020,” Washington Examiner, January 9, 2020; Vanessa Williamson and Isabella Gelfand, “Trump and racism: What do the data say?" Brookings, August 14, 2019.

85 Laurel Bliss and Brian Schaffner, "10\% of Trump 2016 Voters Might Not Vote for Him in 2020," Vox, March 10, 2020. 
Electoral considerations aside, what stands out are the ways in which Trump's tactical efforts to dominate and personalize his party and his strategic emphasis on base mobilization have been complementary and mutually reinforcing. By demanding and obtaining fealty from almost all elected and appointed Republicans while investing in the party's organizational capacities, Trump has ensured that the Republican Party organization is a responsive and reliable instrument with which to mobilize his base. Energetic base mobilization, in turn, has bolstered Trump's efforts to dominate and control his party by arousing grassroots supporters and encouraging them to put bottom-up pressure on Republican elites to demonstrate continued loyalty to the president. Trump's heavy-handed tactics and strategies, in other words, have worked synergistically to transform the Republican Party into a formidable tool of presidential power. They have been complementary in ways that have contributed to partisan polarization, allowed Trump to claim democratic legitimacy for his controversial behaviors, and all but eliminated the possibility that fellow Republicans will hold him accountable to collective party interests. But before exploring these consequences in greater detail, let us consider why Trump has diverged from the traditional Republican party-building pattern.

\section{Explaining Trump's Variation on the Party- Building Theme}

Trump's use of traditional Republican party-building tactics in pursuit of a predominantly base mobilization-centered strategy raises the question: why this variation on the theme?

Much of the explanation undoubtedly involves the twin developments of party sorting and partisan polarization, arguably the most conspicuous features of contemporary politics. ${ }^{86}$ In this context, in which cross-pressured, ticket-splitting voters are in decline, Trump's strategy may seem more rational, efficient, and attractive than a more outward-reaching, median-voter focused, "persuasion"

86 Matthew Levendusky, The Partisan Sort: How Liberals Became Democrats and Conservatives Became Republicans (University of Chicago Press, 2009); Nolan McCarty, Polarization: What Everyone Needs to Know (Oxford University Press, 2019); Ezra Klein, Why We're Polarized (Simon \& Schuster, 2020). 
strategy, especially if the opposition lags behind or is demobilized or disenfranchised (which appears to be a concomitant strategy). ${ }^{87}$ Partisan polarization has also been described as a cause of Trump's rise to power in the first place which may help to explain why his strategy seems such a natural "fit" with his political environment. ${ }^{88}$

Relatedly, the consolidation of the two parties' geographical bases of support - where votes for presidential, Senate, and House candidates have become increasingly aligned in recent years ${ }^{89}$ - and the imperatives of the Electoral College may well recommend a strategy focused on reassembling Trump's 2016 electoral coalition and boosting the turnout of groups that supported him in his first election. ${ }^{90}$ It is certainly not an irrational or implausible path to victory: Republicanleaning geographic areas now constitute a sufficient base to win control of government.

And yet, there was nothing structurally predetermined or inevitable about Trump's choice of strategies. Recall that the Republican National Committee's 2013 "Growth and Opportunity Project” report (aka "the GOP autopsy") called for more inclusive rhetoric, more centrist policies, and more serious outreach efforts to

87 E.g. Costas Panagopoulos, "All About That Base: Changing Campaign Strategies in Us Presidential Elections," Party Politics 22 (2016): 179-190; Corwin D. Smidt, "Polarization and the Decline of the American Floating Voter.” American Journal of Political Science 61, no. 2 (2017): 365-381; Joshua L. Kalla and David E. Broockman, "The Minimal Persuasive Effects of Campaign Contact in General Elections: Evidence from 49 Field Experiments," American Political Science Review 112, no. 1 (2018): 148-166. On the decline of ticket splitting, see, for example, Philip Bump, “The Decline and Fall of Split-Ticket Voting, Visualized," The Washington Post, May 20, 2016; Drew Desilver, "Split-ticket districts, once common, are now rare," Pew Research Center, August 8, 2016. On voter suppression, see: Sam Levine, “Trump Says Republicans Would 'Never' Be Elected Again if it was Easier to Vote,” The Guardian, March 30, 2020.

88 Byron E. Shafer and Regina L. Wagner, "The Trump Presidency and the Structure of Modern American Politics,” Perspectives on Politics 17, 2 (2019): 340-357; Sidney M. Milkis and Nicholas Jacobs, “II Alone Can Fix It': Donald Trump, the Administrative Presidency, and Hazards of Executive-Centered Partisanship,” The Forum (2017), 583-613; Robert C. Lieberman, Suzanne Mettler, Thomas B. Pepinsky, Kenneth M. Roberts and Richard Valelly, "The Trump Presidency and American Democracy: A Historical and Comparative Analysis," Perspectives on Politics 17, 2 (2019): 470-479.

89 Jeffrey M. Stonecash, Party Pursuits and the Presidential-House Election Connection, 19002008 (New York: Cambridge University Press, 2012); Alan I. Abramowitz, The Great Alignment: Race, Party Transformation, and the Rise of Donald Trump (New Haven: Yale University Press, 2018), pp. 62-63.

90 David Hopkins, Red Fighting Blue: How Geography and Electoral Rules Polarize American Politics (New York: Cambridge University Press, 2017); Nicole Mellow, The State of Disunion: Regional Sources of Modern American Partisanship (Baltimore: Johns Hopkins University Press, 2008). 
Latinos, women, African Americans, and young people. ${ }^{91}$ It is not difficult to imagine a President Marco Rubio or a President Jeb Bush (or John Kasich or Chris Christie) taking those recommendations seriously and engaging in outreach along precisely those lines. But it was Donald Trump who secured the Republican nomination - a remarkable outcome in its own right - and Trump has made the deliberate choice to ignore the autopsy report's recommendations and go his own way.

The latter point, of course, directs our attention to another plausible explanation for Trump's variation on the party-building theme: the loosening of traditional selection-system constraints and the failure of party insiders to coordinate their efforts in time to prevent Trump, an outsider candidate, from successfully executing a "hostile takeover" of the Republican Party. ${ }^{92}$ Trump's loose affiliation with the party may thereby help to explain his single-minded focus on advancing his personal interests and apparent lack of concern for the party's long-term prospects (Eisenhower's assiduous party building despite his similarly loose affiliation with the GOP complicates this explanation, but does not rule it out).

Or perhaps Trump's strategic choices simply reflect the distinctive and idiosyncratic elements of his personality. His unprecedented approach to party leadership is only one of the ways in which Trump differs from his Republican predecessors. His overt demagogy; his adept use of Twitter and shrewd manipulation of the media; his unapologetic departures from conservative orthodoxy on issue after issue; his divisive, xenophobic, hateful rhetoric; his abuses of power and brazen corruption; his intolerance of divergent viewpoints and contradictory facts, even when delivered by scientists, doctors, and experts in his own administration; the delight he appears to take in breaking traditional norms of presidential behavior - all of these differences may simply be explained by individuallevel and psychological factors. Relatedly, his apparent urge to surround himself with fawning admirers (potentially narcissistic personality disorder), sociopathic and authoritarian tendencies, and so forth, may have made his adrenalized basemobilization strategy more personally gratifying. ${ }^{93}$

It could also be that Trump has stumbled upon a distinctive message and worldview that resonates deeply with his base but does not travel much beyond it. This may leave him boxed in, hoping that his base-mobilization strategy -

91 Republican National Committee, “Growth and Opportunity Project," https://www. documentcloud.org/documents/624581-rnc-autopsy.html.

92 Marty Cohen, David Karol, Hans Noel and John Zaller, "Party Versus Faction in the Reformed Presidential Nominating System,” PS: Political Science \& Politics 49 (2016): 701-708; Julia Azari, "Weak Parties and Strong Partisanship Are a Bad Combination," Mischiefs of Faction (2016).

93 On Trump's psychological profile, see, for example: https:/www.psychologytoday.com/us/ basics/president-donald-trump; Douglas Kellner, American Nightmare: Donald Trump, Media Spectacle, and Authoritarian Populism (Springer, 2016). 
combined with some amount of Democratic demobilization and other voter suppression strategies to bias the outcome in his favor - will be sufficient to win. ${ }^{94}$ Or perhaps Trump's approach has been shaped by the distinctive challenges of lateregime maintenance and his tenuous affiliation with his adopted party - key characteristics of Trump's moment in "political time," as described by Stephen Skowronek - and his base-maximization strategy offers a route to boosting his support within a party that is more deeply fractured than it appears. ${ }^{95}$

Some combination of the above factors likely helps to explain Trump's variation on the Republican party-building pattern - although there are surely other factors at work as well. But the more pressing question remains: what should we make of all this? What are the potential implications of Trump's distinct style of party leadership, and what does it tell us about the president-party relationship?

\section{Discussion}

Thus far, Trump has managed to avoid many of the party-building dilemmas that frustrated his Republican predecessors. For them, party-building meant majoritybuilding, which meant welcoming a greater diversity of opinions into the party, opening the party to new policy positions, and drawing in a more heterogeneous mix of party leaders who could forge connections with a broad range of prospective voters, activists, donors, and candidates. Those dynamics incrementally advanced the presidents' majority-building objectives but abraded against their "quest for control" over their party. ${ }^{96}$ Most often, they found they could not achieve both at the same time.

By swapping his predecessors' outreach-focused strategies for a predominantly base-mobilization strategy - while simultaneously dominating his party and investing in its organizational capacities - Trump has brought an unprecedented degree of congruence to the president-party relationship. This congruence is evident in how thoroughly Trump has managed to turn the Republican Party into

94 Joanna Walters, “Top Trump adviser: Republicans have 'always' relied on voter suppression,” The Guardian, December 21, 2019.

95 Stephen Skowronek, Presidential Leadership in Political Time: Reprise and Reappraisal, Third Edition (Lawrence: University Press of Kansas, forthcoming). Also see Julia Azari, “Trump's Presidency Signals the End of the Reagan Era," Vox, December 1, 2016; Thomas B. Edsall, "The Fight Over How Trump Fits in With the Other 44 Presidents," The New York Times, May 15, 2019. 96 "Quest for control" is from Terry Moe, "Presidents, Institutions, and Theory," in Researching the Presidency, ed. George C. Edwards, III, John H. Kessel, and Bert A. Rockman (Pittsburgh: University of Pittsburgh Press, 1993), 364. 
a "personal" party that now serves as a vehicle for advancing his political purposes and augmenting his power.

The potential implications of this development, should it continue, are serious. Many commentators have pointed to Trump's norm-breaking and authoritarian tendencies only to point the finger at Trump as a person - his psychological makeup, his background experiences, his self-interested calculations, and so on. But to focus only on Trump's personality or behavior without considering the effects of his peculiar approach to party building is to overlook the key contextual factor that makes his behavior so potentially problematic.

With his amped-up base and beefed-up party organization, and with would-be dissenters expelled from the party's leadership, the party collectivity presents a united front of cheerleaders, apologists, and uncritical supporters of almost anything the president might do. This creates the semblance of broad sanction for Trump's behavior; it conveys the party's collective approbation for his more reckless and potentially dangerous impulses (such as inciting violence, questioning the legitimacy of election outcomes, threatening to investigate and punish political opponents, and more). ${ }^{97}$ Presidential behavior that might have otherwise been universally denounced as despotic and system-threatening instead enjoys the unqualified backing of one of the two major political parties. Trump's distinctive combination of party-building tactics and strategies, in other words, has endowed his behavior with the appearance of democratic legitimacy.

This semblance of democratic legitimacy bestowed on Trump's actions by his unified and faithful party - much of it real, but much of it carefully cultivated, curated, and required as a condition of membership - also makes it easier for the press and the public to write off potentially serious interbranch conflict as justmore partisan conflict. In the context of heightened partisan polarization, this interpretation is understandable. But it overlooks how Trump has labored to manufacture this support through his distinctive style of party leadership. By fusing familiar party-building tactics with an unusually focused base-mobilization strategy, Trump's distinctive mode of party leadership has exacerbated partisan polarization, encouraged others to view his behavior only in that light, and thereby contributed to the enervation of the constitutional system. ${ }^{98}$

97 E.g. David Leonhardt, “It Isn’t Complicated: Trump Encourages Violence,” The New York Times, March 17, 2019; Steven Levitsky and Daniel Ziblatt, How Democracies Die (Broadway Books, 2018).

98 For a penetrating analysis of the dangers of Trump's executive aggrandizement in this context, see Nicholas F. Jacobs, Desmond King and Sidney M. Milkis, "Building a Conservative State: Partisan Polarization and the Redeployment of Administrative Power," Perspectives on Politics 17, 2 (2019): 453-469. 
As political scientists Steven Levitsky and Daniel Ziblatt have written, preventing "democratic backsliding" requires that party insiders are willing to call out the demagogue's anti-democratic behavior, withhold their endorsements, refuse to align themselves with him or her, and even buck the leader or actively work to oppose them. ${ }^{99}$ By setting in motion a self-perpetuating cycle of party domination, base-mobilization, and organizational investment, Trump has made such courageous pro-democracy moves far more difficult and much less likely, at least for the foreseeable future. Rather than stand up to Trump, many influential Republicans have either fallen in line and become sycophants (like Senator Lindsey Graham) or removed themselves from politics altogether (like former House Speaker Paul Ryan). ${ }^{100}$ Perhaps would-be dissenters are simply biding their time, waiting Trump out, and optimistically hoping that the Republican Party will re-embrace the more pluralistic commitments embodied in the 2013 RNC autopsy report after Trump leaves the scene. Retired Republican Senator Bob Corker, for example, said: "I hope this is a very temporary place for the Republican Party ... I hope that very soon we will return to our roots as a party that's very different, especially in tone, from what we've seen coming out of the White House."101 Perhaps Corker's hopes will someday come true. But in the meantime, the absence of potential objectors in the party contributes further to the cycle of party domination and presidential empowerment.

If Trump continues to eschew majority-building through outreach, his path to victory in 2020 may remain narrow and his margin for error quite small - which may incentivize the president and his personalized party to pursue antidemocratic initiatives even more vigorously. Efforts to demobilize or suppress likely Democratic voters, especially nonwhite Democratic voters, by raising the barriers to voting - e.g. fighting efforts to expand vote-by-mail options amid the COVID-19 pandemic, purging voters from registration rolls, closing polling places,

99 Levitsky and Ziblatt, How Democracies Die.

100 Alexandra Hutzler, "Republicans Abandoning GOP Under Trump," Newsweek, July 5, 2019; Rachel Bade, "Trump's takeover of GOP forces many House Republicans to head for the exits," The Washington Post, September 22, 2019.

101 "The Republican Party is kind of taking a nap somewhere," said former House Speaker John Boehner. But a different former Republican House Speaker, Newt Gingrich, held a different view: "The anti-Trump movement is gradually being pushed to the side ... He is growing a Trump Republican Party which will turn the never-Trumpers into a fossilized remnant of bitter-enders." Steve Peoples, "In a party dominated by Trumpism, growing ranks of forgotten Republicans sound warning," Chicago Tribune, August 18, 2018; Janet Hook, “It is the era of Trump': How the President is Remaking the Republican Party,” The Wall Street Journal, August 27, 2018. 
introducing stricter voter ID laws, as well as gerrymandering and efforts to block prodemocracy initiatives like automatic registration and ending felon disfranchisement - become all the more likely. Whereas the "politics of addition" requires party leaders to take steps to expand the electorate, the base mobilization strategy - especially one grounded in a racialized, us-versus-them message - requires precisely the opposite. As opinion writer Jennifer Rubin has written in critique, "Faced with the reality that they have chased off nonwhite voters at an alarming rate, they've now morphed into the party of white grievance, xenophobia and racism. The only way to win with that kind of message in a racially pluralistic society is to make sure the electorate isn't so pluralistic." ${ }^{\text {"102 }}$. Indeed, as Jacob Hacker and Paul Pierson have written, anti-democratic initiatives may well be necessary if Republican elites and their plutocratic allies are to establish "sustained minority rule" ... "because democracy itself is a threat to plutocratic resources and power". 103

Many twists in the road surely still lie ahead, especially given the extreme uncertainty surrounding COVID-19, how the pandemic will affect the mechanics of voting, and the evaluations voters will form regarding the president's handling of the crisis. But by comparing Trump's party leadership to that of his predecessors, this paper has endeavored to identify more precisely "what's new" about his approach during the first three-plus years of his presidency. I have argued that while Trump's tactics are familiar, his purposes have diverged in important ways from earlier Republicans', and this divergence spotlights the crucial relationship between tactics and strategies in presidential leadership projects. Trump's particular combination of party domination, organizational investment, and base mobilization are complementary in ways that enhance presidential power, reflect and reinforce partisan polarization, and project the semblance of popular legitimacy for the president's more questionable behaviors. At the same time, they reduce the likelihood that intraparty forces will be able to provide an effective check on Trump's aggrandizement of executive power and increase the likelihood that Trump and his followers will push for more antidemocratic reforms.

This comparative-historical perspective on Trump's party leadership also highlights another pattern that bears on our assessment: the asymmetrical partisan pattern of presidential party leadership, which appears to have endured

102 Jennifer Rubin, "Republicans are anti-voting and anti-democratic," The Washington Post opinion, April 12, 2019.

103 Jacob S. Hacker and Paul Pierson, Let them Eat Tweets: How the Right Rules in an Age of Extreme Inequality (New York: W.W. Norton, 2020), 172, 179. 
in its fundamentals well into the 21st century. ${ }^{104}$ Democratic and Republican presidents have continued to forge qualitatively different relationships with their parties. The contrast between Obama's party leadership and Trump's, as well as the extent to which each president's choices insulated him politically, could not be starker. Indeed, it is somewhat ironic that many Democrats lamented Obama's reluctance to provide his party with more direction, criticized his neglect of its organizational apparatus, regretted his disinclination to get more personally involved in the campaigns of fellow partisans, and bemoaned his refusal to develop a collective strategy for the party. As we have seen, these are the very components of Trump's party leadership that have generated such concern.

On the flip side, the persistence of the asymmetrical partisan pattern suggests that Trump's party leadership may not necessarily reflect a durable, systemic shift in president-party relations. Such a shift would require future Democratic presidents to follow in Trump's footsteps. Although that is not impossible, it may be more difficult for future Democratic presidents to pull off given the more heterogeneous, ideologically diverse, group-based Democratic Party coalition and its abiding commitment to inclusion and pluralism in party affairs. ${ }^{105}$ For now, at least, it appears likely to remain a distinctly Republican phenomenon - or, time will tell, perhaps just a Trump-specific phenomenon.

Finally, it remains entirely possible that Trump may yet fall back into the traditional Republican pattern and respond to the same outward-reaching, majority-building imperatives that propelled his partisan predecessors. As noted above, the Trump campaign will likely feel pressure to do more swing-voter outreach as the 2020 election approaches, especially with the Democrats poised to nominate the more centrist Joe Biden, who jumped to an early lead in several key

104 Galvin, Presidential Party Building (2010). In recent years, scholars have identified additional dimensions of party asymmetry, confirming that political parties in the U.S. tend not to converge - as might be expected if organizational isomorphism or "Downsian" competition for the median voter were the only factor at work - but often diverge and differentiate. See especially Matt Grossmann and David A Hopkins, Asymmetric Politics: Ideological Republicans and Group Interest Democrats (Oxford University Press, 2016); Boris Heersink, "Party Brands and the Democratic and Republican National Committees, 1952-1976.” Studies in American Political Development 32, 1 (2018): 79-102; Ezra Klein, Why We're Polarized (Simon \& Schuster, 2020), ch. 9. For earlier work in this vein, see David R. Mayhew, Party Loyalty among Congressmen: The Difference between Democrats and Republicans, 1947-1962 (Harvard University Press, 1966); Jo Freeman, "The Political Culture of the Democratic and Republican Parties,” Political Science Quarterly 101, 3 (1986): 327-356; Philip A. Klinkner, The Losing Parties: Out-Party National Committees, 1956-1993 (New Haven: Yale University Press, 1994); John Gerring, Party Ideologies in America, 1828-1996 (Cambridge University Press, 2001).

105 Ibid.; also see Marc J. Hetherington and Jonathan D. Weiler, Authoritarianism and Polarization in American Politics (Cambridge University Press, 2009). 
battleground states (in April 2020). ${ }^{106}$ What is more, if states' stay-at-home orders persist into the fall, the Trump-RNC campaign may need to rely more on digital and television advertisements than in-person canvassing, which would allow it to custom-tailor messages to appeal to swing voters who have thus far largely disapproved of the president's handling of the coronavirus pandemic. ${ }^{107}$ Although the distinction between short-term campaign strategies and long-term partybuilding strategies is often blurred in election years, it would not be surprising to see Trump incorporate some of those 2020 swing-voter outreach efforts into a longer-term party-building strategy in a potential second term - especially if divided government persists. ${ }^{108}$ In other words, it is unclear how long he can hold fast to a predominantly base-focused strategy. On the other hand, with partisan polarization reaching new heights (evident even in responses to the coronavirus $^{109}$ ) and Trump's personal proclivities and psychological traits unlikely to change any time soon, he may not perceive any reason to change course. We shall see.

Acknowledgments: The author wishes to thank Sean Diament, Katie Glassmyer, Boris Heersink, David Hopkins, Matthew Lacombe, Warren Snead, Stephen Skowronek, and Jeffrey Stonecash for helpful comments.

106 Rebecca Klar, "Trump lashed out at campaign manager over polling showing him trailing Biden: reports,” The Hill, April 29, 2020; Alex Isenstadt, “Trump’s poor poll numbers trigger GOP alarms over November," Politico, April 24, 2020.

107 See, for example, Robert Draper, "Can the Trump Campaign Rewrite the Story of the Trump Presidency?” The New York Times Magazine, April 28, 2020.

108 On structural and competitive party-building incentives, see Galvin, Presidential Party Building.

109 Shana Kushner Gadarian, Sara Wallas Goodman, and Thomas B. Pepinsky, "Partisanship, Health Behavior, and Policy Attitudes in the Early Stages of the COVID-19 Pandemic" (SSRN Working Paper, March 27, 2020), available at https://ssrn.com/abstract=3562796 or https://doi. org/10.2139/ssrn.3562796. 